\title{
PENGARUH TINGKAT PENDIDIKAN DAN PENDAPATAN \\ ORANG TUA TERHADAP PRESTASI BELAJAR IPS SISWA KELAS VIII DI MTS AZZAINIYAH I RANDUMERAK KECAMATAN PAITON KABUPATEN PROBOLINGGO TAHUN AJARAN 2013/2014
}

\author{
Solehoddin \\ Universitas Kanjuruhan Malang \\ Email: Soleho@gmail.com
}

\begin{abstract}
Abstrak
Pendidikan di sekolah merupakan suatu usaha untuk membantu siswa dalam perkembangan sesuai dengan bakat dan kemampuan anak. Tingkat keberhasilan dari masing-masing anak banyak dipengaruhi oleh beberapa faktor antara lain faktor latar belakang keluarga, tingkat pendidikan, dan tingkat pendapatan orang tua yang mempengaruhi prestasi belajar siswa. Metode penelitian yang digunakan dalam penelitian ini adalah metode data primer yang berupa angket dan dan sekunder yang berupa rapot siswa semester I mata pelajaran IPS kelas VIII Di MTs Azzainiyah I Randumerak,Kecamatan paiton Kabupaten Probolinggo Tahun pelajaran 2013/2014 .berdasarkan hasil penelitian didapatkan dan setelah diadakan analisis data diperoleh rhitung (X1) sebesar 0,759 dan rhitung (X2) sebesar 0,617 sedangkan thitung (X1) sebesar 0,035 dan thitung (X2)sebesar 0,011. Sedangkan Fhitung sebesar 0,000 dan kontribusi efektif dari kedua variabel tingkat pendidikan dan tingkat pendapatan orang tua tersebut sebesar $62,9 \%$. terhadap prestasi belajar dan sisanya sebesar $37,1 \%$.dari kesimpulan di atas ada pengaruh yang positih dan signifikan antara pendidikan dan pendapatan orang tua terhadap prestasi belajar siswa.
\end{abstract}

Kata Kunci: Pendidikan dan pendapatan orang tua, prestasi siswa

\section{PENDAHULUAN}

Di era globalisasi seperti sekarang ini mutlak menuntut seseorang untuk membekali diri dengan ilmu pengetahuan agar dapat bersaing dan mempertahankan diri dari semakin kerasnya kehidupan dunia dan dari berbagai tantangan yang mau tidak mau harus dihadapi. "Pendidikan merupakan salah satu faktor utama bagi pengembangan sumber daya manusia karena pendidikan diyakini mampu meningkatkan sumber daya manusia sehingga dapat menciptakan manusia produktif yang mampu memajukan bangsanya" (Kunaryo, 2000). Pendidikan dalam arti luas didalamnya terkandung pengertian mendidik, membimbing, mengajar dan melatih. Dalam keseluruhan proses pendidikan di sekolah, kegiatan belajar merupakan kegiatan yang paling pokok.

Keluarga merupakan lembaga sosial pertama yang dikenal oleh anak dan dalam keluarga tersebut dapat ditanamkan sikap-sikap yang dapat mempengaruhi perkembangan anak selanjutnya. Keluarga bertanggung jawab menyediakan dana untuk kebutuhan pendidikan anak. Keluarga (orang tua) yang keadaan sosial ekonominya tinggi tidak akan banyak mengalami kesulitan dalam memenuhi kebutuhan sekolah anak, berbeda dengan orang tua yang keadaan sosial ekonominya rendah. Contohnya: anak dalam belajar akan sangat memerlukan sarana penunjang belajarnya, yang 
kadang-kadang harganya mahal. Bila kebutuhannya tidak terpenuhi maka ini akan menjadi penghambat bagi anak dalam pembelajaran. Sehubungan dengan hal tersebut keberhasilan suatu pendidikan ditunjang oleh beberapa faktor diantaranya kondisi sosial ekonomi yang meliputi sarana dan prasarana.

Terbatasnya sarana bacaan, fasilitas belajar, dan kadang-kadang tidak terpenuhinya kebutuhan pendidikan dari zorang tua siswa sehingga kurang memperhatikan pelajaran dengan baik, akhirnya tertinggal dalam hal prestasi. Dari pengamatan dan informasi yang diperoleh di lapangan bahwa siswa yang ada di sekolah tersebut berasal dari latar belakang keadaan sosial ekonomi keluarga yang berbeda, seperti: pendapatan, kekayaan yang dimiliki dan tempat tinggal dapat berpengaruh terhadap prestasi belajar. Bukan hanya tingkat pendapatan orang tua yang dapat mempengaruhi prestasi belajar siswa seperti tingkat pendidikan juga akan mempengaruhi prestasi belajar siswa.

Tingkat pendidikan orang tua akan men entukan cara orang tua dalam membimb in dan mengarahkan anaknya dalam hal pendidikan. Tingkat pendidikan orang tua yang rendah akan cenderung sempit wawasannya terhadap pendidikan, sedangkan pendidikan orang tua yang ti nggi akan lebih luas wawasannya terhad ap pendidikan. Mereka akan mengarahkan dan membimbing anaknya untuk terus menambah ilmu sehingga anak tersebut mempunyai semangat dalam belajar.

Hal yang seperti itu terjadi di MTs Azzainiyah 1 Randudmerak, di mana sekolah ini menampung peserta didik dari berbangai macam latar belakang yang berbeda seperti keadaan tingkat pendapatan dan tingkat pendidikan orang tua keragaman latar belakang pendapatan orang tua dapat mempengaruhi pada kemampuan orang tua membiayai sekolah anaknya, sehingga keadaan pendapatan orang tua merupakan salah satu faktor yang mentukan keberhasilan pendidikan anak.

Dari hasil pengamatan sekilas di MTs Azzainiyah 1 Randumerak dan data dari sekolah rata-rata pekerjaan orang tua siswa petani dengan penghasilan kurang dari Rp 1.000.000,00, selain itu pendidikan orang tua siswa di sekolah tersebut rata-rata hanya tamat SD (Sekolah Dasar) hal tersebut tentunya sedikit banyak akan mempengaruhi pencapaian prestasi belajar siswa di sekolah. Walaupun demikian tingkat prestasi belajar siswa tidak dapat seluruhnya dapat dilihat dari tingkat pendapatan orang tua, Tingkat pendapatan dan pendidikan orang tua yang lebih tinggi dapat mendorong prestasi belajar siswa dan tingkat pendapatan orang tua yang rendah dapat menghambat prestasi belajar siswa.

Dalam pencapaian prestasi tersebut motivasi siswa juga dapat memberikan pengaruh, hanya saja dalam penelitian ini tidak dimasukan dalam variabel penelitian. Sebab tindak banyak siswa dari keluarga berlatar belakang pendidikan dan pendapatan orang tua rendah memiliki motivasi yang tinggi dalam belajar. Tetapi juga perlu di perhatiak tingkat pendidikan orang tua dapat mempengaruhi prestasi belajar anak di sekolah karena dalam sebuah keluarga orang tua merupakan pusat pendidikan yang mana pendidikan juga terjadi pada lingkungan keluarga maka di perlukanya tingkat pendidikan orang tua yang lebih tinggi karna jika tingkat pendidikan orang tua rendah sangat mempengaruhi prestasi belajar siswa, 
tingakt pendidikan orang tua dapat di lihat dari sifat dan perhatian orang tua terhadap anaknya. Orang tua mempunya peran yang cukup besar terhadap tingkat perstasi belajar sisw

\section{METODE PENELITIAN}

Dalam penelitian ini menggunakan langkah-langkah sebagai berikut:

a. Rancangan Penelitian.

1. Variabel bebas adalah variabel yang mempunyai fungsi sebagai stimulasi, penyebab bagi variabel lain yang akan diteliti, adapun yang menjadi variabel bebas dalam penelitian ini adalah tingkat pendidikan sebagai variabel bebas pertama (X) dan pendapatan orang tua sebagai variabel bebas kedua (X2).

2. Variabel terikat adalah variabel yang timbul dari hubungan fungsional dari variabel bebas dalam penelitian ini variabel terikat adalah prestasi belajar siswa dalam mata pelajaran IPS Terpadu (Y).

b. Subjek penelitian

Subjek penelitian ini adalah siswa kelas VIII MTs Azzainiyah I Desa Randumerak Kecamatan Paiton Kabupaten Probolinggo yang masih aktif mengikuti kegiatan belajar mengajar sebanyak 21 siswa karena kita mengambil subjek penelitiannya keseluruhan, supaya dapat mengetahui tingkat pendidikan dan pendapatan orang tua siswa yang terdistribusikan dalam 1 (Satu) kelas karena peserta didik tersebut mempunyai bermacam karakter yang berbeda dan mempunyai kemampuan belajar tergantung dari hasil belajar peserta didik. c. Intrumen Penelitian

Dalam penelitian ini sesuai dengan tujuan yang diharapkan, yaitu mengetahui apakah ada pengaruh yang signifikan antara tingkat pendapatan orang tua dengan prestasi belajar siswa, maka diperlukan data tentang tingkat pendidikan orang tua dan tingkat pendapatan orang tua.Instrumen yang digunakan untuk mengumpulkan data tentang tingkat pendidikan dan pendapatan orang tua adalah angket sedangkan prestasi belajar siswa nilai akhir semester 1 tahun pelajaran 20142015 yang dimiliki oleh guru bidang studi.

\section{HASIL DAN PEMBAHASAN}

a. Uji Validitas

Analisis validitas berfungsi untuk menunjukkan tingkat kesahihan suatu instrument. Instrument yang sahih memiliki validitas tinggi. Instrument dikatakan sahih jika mampu mengukur apa yang diinginkan dan mampu mengungkapkan data dari variabel yang diteliti secara tepat, serta tinggi rendahnya instrument menunjukkan sejauh mana data yang terkumpul tidak menyimpang dari gambaran variabel yang dimaksud. Hasil analisis validitas ditunjukkan dengan membandingkan nila $r_{\text {hitung }}$ dengan nilai $r_{\text {tabel }}(0,433)$. Apabila $r_{\text {hitung }}>0,433$ maka butir soal atau pernyataan yang disajikan adalah valid.Hasil analisis validitas yang didistribusikan kepada 21 responden adalah sebagai berikut: 
Tabel 1 .Hasil Uji Validitas Item Tingkat Pendidikan Orang Tua

\begin{tabular}{cccc}
\hline $\begin{array}{c}\text { Item } \\
\text { Pertanyaan }\end{array}$ & $\mathbf{r}_{\text {hitung }}$ & $\mathbf{r}_{\text {tabel }}$ & Status \\
\hline 1 & 0,588 & 0,433 & Valid \\
2 & 0,539 & 0,433 & Valid \\
3 & 0,701 & 0,433 & Valid \\
4 & 0,510 & 0,433 & Valid \\
5 & 0,677 & 0,433 & Valid \\
6 & 0,540 & 0,433 & Valid \\
\hline
\end{tabular}

Dari tabel 1. di atas menggambarkan hasil uji validitas untuk masing-masing item pertanyaan variabel latar belakang pendidikan orang tua, dimana dari 6 item yang disajikan kepada responden, seluruhnya menunjukkan hasil yang valid (sah), sedangkan item-item pertanyaan yang gugur (tidak valid) tidak ada.

Tabel 2. Hasil Uji Validitas Item Tingkat Pendapatan Orang Tua

\begin{tabular}{cccc}
\hline $\begin{array}{c}\text { Item } \\
\text { Pertanyaan }\end{array}$ & $\mathbf{r}_{\text {hitung }}$ & $\mathbf{r}_{\text {tabel }}$ & Status \\
\hline 1 & 0,467 & 0,433 & Valid \\
2 & 0,520 & 0,433 & Valid \\
3 & 0,737 & 0,433 & Valid \\
4 & 0,700 & 0,433 & Valid \\
5 & 0,455 & 0,433 & Valid \\
6 & 0,553 & 0,433 & Valid \\
7 & 0,504 & & Valid \\
\hline
\end{tabular}

Dari tabel 2 di atas menggambarkan hasil uji validitas untuk masing-masing item pertanyaan variabel pendapatan orang tua, dimana dari 7 item yang disajikan kepada responden, seluruhnya menunjukkan hasil yang valid (sah), sedangkan item-item pertanyaan yang gugur (tidak valid) tidak ada

\section{b. Uji Reliabilitas}

Uji reliabilitas menunjukkan sejauh mana instrument dapat memberikan hasil pengukuran yang konsisten jika ada pengulangan pengukuran. Metode yang digunakan dalam analisis reliabilitas ini adalah metode AlphaCronbach. Nilai Alpha-Cronbach (r alpha) program SPSS 20 for Windows ditunjukkan oleh besarnya nilai Alpha (a). Pengambilan keputusan reliabilitas suatu variabel ditentukan dengan melihat kategori nilai r Alpha. Jika nilai Alpha adalah $0,80-1,00$ maka reliabilitasnya termasuk baik, dan jika nilai Alpha adalah 0,60 - 0,79 maka reliabilitasnya termasuk kategori dapat diterima (Sekaran, $200: 312$ ). Hasil uji reliabilitas masing-masing variabel bebas dalam penelitan ini dapat dilihat pada table berikut ini:

3. Hasil Uji Reliabilitas Variabel

Tabel 3. Uji Reliabilitas Variabel

\begin{tabular}{lll}
\hline Variabel & $\begin{array}{l}\text { Alpha } \\
\text { Cronbach }\end{array}$ & Status \\
\hline X1 & 0,608 & Baik \\
X2 & 0,620 & Baik \\
\hline
\end{tabular}

Hasil uji reliabilitas dalam table 3 di atas menunjukkan bahwa nilai Alpha Cronbach dari masing-masing variabel, yaitu 0,608 untuk variabel tingkat pendidikan orang tua (X1) dan 0,620 untuk variabel tingkat penghasilan orang tua (X3), dimana kedua variabel bebas tersebut memiliki status reliabilitas baik. 


\section{Tingkat Pendidikan Orang Tua (X1)}

Berdasarkan data yang diperoleh dari TU MTs Azzainiyah 1 Randumerak dapat diketahui bahwa sebagian besar tingkat pendidikan orang tua adalah SMA/sederajar dan SMP yaitu masingmasing sebanyak 8 orang (38\%), sedangkan 5 orang lainnya (24\%) berpendidikan setingkat SD. Hasil

Berdasarkan data yang di peroleh diketahui bahwa tingkat pendidikan yang berkategori sangat tinggi adalah perguruan tinggi (PT) adalah 0 orang $(0 \%)$, kategori tinggi atau setingkat SMA/sederajat sebanyak 8 orang (38\%), kategori cukup adalah setingkat SMP sebanyak 8 orang (38\%), kategori rendah adalah setingkat SD yaitu sebanyak 5 orang (24\%) dan kategori sangat rendah yaitu orang yang tidak pernah sekolah sebanyak 0 orang $(0 \%)$. Dengan demikian tingkat pendidika orang tua siswa kelas VIII di MTs Azzainiyah 1 Randumerak dalam kategori tinggi atau tamat SMA/sederajat dan cukup atau tamat SMP yang masing-masing sebanyak 8 orang.

\section{Tingkat Pendapatan Orang Tua (X2)}

Pengolahan data yang dilakukan oleh peneliti terhadap hasil penyebaran angket tingkat penghasilan orang tua sebanyak 21 siswa adalah dengan melakukan penskoran perhitungan yang dilakukan peneliti terhadap masingmasing variabel. Hasil skor mentah angket tingkat pendapatan orang tua ada pada lampiran. Data mengenai tingkat pendapatan orang tua siswa kelas VIII di MTs Azzainiyah 1 Randumerak yang berjumlah 21 siswa memiliki skor tertinggi 28 sedangkan skor terendah sebesar 10 yang secara lengkap dapat dilihat pada lampiran. Berdasarkan data tersebut dapat dihitung dengan menggunakan frekuensi dan prosentase.

Tabel 4. Hasil Frekuensi dan Prosentase Tingkat Pendapatan Orang Tua

\begin{tabular}{lllcc}
\hline No & Kategori & Pendidikan & Jumlah & $\%$ \\
\hline 1 & $\begin{array}{l}\text { Sangat } \\
\text { Tinggi }\end{array}$ & $30-35$ & 0 & $0 \%$ \\
2 & Tinggi & $24-29$ & 2 & $10 \%$ \\
3 & Cukup & $18-23$ & 2 & $10 \%$ \\
4 & Rendah & $12-17$ & 11 & $52 \%$ \\
5 & $\begin{array}{l}\text { Sangat } \\
\text { Rendah }\end{array}$ & $7-11$ & 6 & $29 \%$ \\
\hline \multicolumn{3}{c}{ Jumlah } & & 21 \\
\hline
\end{tabular}

Dari data tersebut terlihat bahwa tingkat pendapatan orang tua siswa dengan kategori sangat tinggi adalah 0 orang (0\%), kategori tinggi adalah 2 siswa atau $10 \%$, kategori cukup yaitu 2 orang atau $10 \%$, kategori rendah sebanyak 11 orang atau 52\% dan kategori sangat rendah sebanyak 6 orang atau $29 \%$. Dengan demikian secara umum dapat dikategorikan bahwa tingkat pendapatan orang tua siswa kelas VIII di MTs Azzainiyah 1 Randumerak berada dalam taraf rendah yang lebih dominan.

\section{Prestasi Belajar Siswa (Y)}

Prestasi belajar siswa yang didapat melalui nilai rapor mata pelajaran IPS semester 1 tahun pelajaran 2014/2015 selengkapnya terdapat pada lampiran. Pada table 4.6 akan disajikan nilai rapor IPS siswa dalam bentuk data interval mengenai prestasi belajar. 
Tabel 5. Hasil Frekuensi dan Prosentase

Prestasi Belajar Siswa

\begin{tabular}{lllll}
\hline No & Kategori & Pendidikan & Jumlah & \% \\
\hline 1 & Sangat & $79-84$ & 5 & $24 \%$ \\
& Tinggi & & & \\
2 & Tinggi & $73-78$ & 7 & $33 \%$ \\
3 & Cukup & $67-72$ & 7 & $33 \%$ \\
4 & Rendah & $61-66$ & 1 & $5 \%$ \\
5 & Sangat & $55-60$ & 1 & $5 \%$ \\
& Rendah & & & \\
\hline \multicolumn{5}{c}{ Jumlah } \\
\hline
\end{tabular}

Berdasarkan tabel di atas, terlihat bahwa siswa yang mendapat prestasi belajar dengan kategori sangat tinggi adalah 5 siswa atau 24\%, kategori tinggi sebanyak 7 siswa atau 33\%, kategori cukup juga sebanyak 7 siswa atau 33\%, kategori rendah sebanyak 1 orang atau 5\% dan kategori sangat rendah juga sebanyak 1 orang atau 5\%. Dengan demikian dapat dikatakan bahwa sebagian besar siswa dapat dikategorikan mendapat nilai tinggi dan cukup.

Penelitian ini menggunakan analisis regresi berganda. Analisis ini digunakan untuk mengukur kekuatan dua variabel atau lebih dan juga menunjukkan arah pengaruh antara variabel dependent dengan variabel independent dengan menggunakan rumus sebagai berikut:

$$
\mathrm{Y}=\mathrm{a}+\mathrm{b}_{1} \mathrm{X}_{1}+\mathrm{b}_{2} \mathrm{X}_{2}+\mathrm{e}_{\mathrm{i}}
$$

Adapun hasil perhitungan atau analisis regresi dapat dilihat pada table 4.7 berikut ini. Berdasarkan hasil analisis regresi di atas, maka dapat disusun persamaan regresinya, sebagai berikut:

$$
\underset{0,617 X_{2}}{Y}=50,353+0,759 X_{1}+
$$

Apabila dianalisis lebih lanjut, maka persamaan regresi tersebut menggambarkan bahwa: $\mathrm{a}=50,353 ;$ hal ini menunjukkan besarnya pengaruh tingkat pendidikan orang tua dan tingkat pendapat orang tua terhadap prestasi belajar siswa kelas VIII di MTs Azzainiyah 1 Randumerak tahun pelajaran 2013/2014, yaitu sebesar 50,353 dari setiap kenaikan $1 \%$ tingkat pendidikan orang tua dan tingkat pendapatan orang tua.

$\mathrm{b}_{1}=\begin{aligned} & 0,759 ; \\ & \begin{array}{l}\text { menunjukkan } \\ \text { pengaruh }\end{array}\end{aligned}$ pendidikan orang tua terhadap prestasi belajar siswa kelas VIII di MTs Azzainiyah 1 Randumerak tahun pelajaran 2013/2014 yaitu sebesar 0,759 dari setiap kenaikan $1 \%$ tingkat pendidikan orang tua.

$$
\begin{aligned}
\mathrm{b}_{2}= & 0,617 ; \text { hal ini } \\
& \text { menunjukkan besarnya } \\
& \text { pengaruh tingkat } \\
& \text { pendapatan orang tua } \\
& \text { terhadap prestasi belajar } \\
& \text { siswa kelas VIII di MTs } \\
& \text { Azzainiyah 1 Randumerak } \\
& \text { tahun pelajaran 2013/2014 } \\
& \text { yaitu sebesar 0,617 dari } \\
& \text { setiap kenaikan } 1 \% \text { tingkat } \\
& \text { pendapatan orang tua. }
\end{aligned}
$$

Penelitian ini bertujuan untuk menguji hipotesis-hipotesis dengan menggunakan multiple regression. Analisis regresi berganda menghubungkan satu variabel dependent dengan beberapa variabel independent dalam suatu model prediktif tunggal. Adapun untuk 
menguji hipotesis yang telah diajukan maka dilakukan pengujian sebagai berikut:

\section{Uji Parsial (Uji t)}

Uji parsial atau uji t dilakukan untuk mengetahui pengaruh masing-masing variabel bebas (tingkat pendidikan orang tua dan tingkat pendapatan orang tua) dengan variabel terikat (prestasi belajar siswa). Uji t dapat dicari dengan membandingkan hasil dari probabilitias value. Jika probabilitas $>0,05$ maka $\mathrm{H}_{0}$ diterima dan $\mathrm{H}_{1}$ ditolak, namun jika probabilitas $<0,05$ maka $\mathrm{H}_{0}$ ditolak dan $\mathrm{H}_{1}$ diterima (Priyatno, 2010). Berikut ini hasil uji $t$ dari masing-masing variabel. Atas dasar hasil analisis data yang ditunjukkan pada table 4.8 di atas, maka dapat dijabarkan kesimpulankesimpulan sebagai berikut:

a. Pengaruh tingkat pendidikan orang tua $\left(\mathrm{X}_{1}\right)$ dengan prestasi belajar siswa (Y)

Sesuai dengan data di atas, diketahui bahwa nilai probabilitas signifikansi $\mathrm{X}_{1}$ $=0,035$. Angka tersebut lebih kecil dari angka $0,05 \quad(0,035<0,05)$ yang merupakan angka derajat kepercayaan, maka dapat disimpulkan bahwa terdapat pengaruh yang signifikan antara tingkat pendidikan orang tua dengan prestasi belaja siswa kelas VIII di MTs Azzainiyah 1 Randumerak tahun pelajaran 2013/2014.

\section{Kriteria pengujian hipotesis:}

Dalam pengujian hipotesis penelitian ini, kriteria yang dipakai adalah sebagai berikut:

Hipotesis nol $\left(\mathrm{H}_{0}\right)$ diterima dan hipotesis alternative $\left(\mathrm{H}_{1}\right)$ ditolak, apabila $\mathrm{r}_{\text {hitung }}<\mathrm{r}_{\text {tabel }}$.
Hipotesis nol $\left(\mathrm{H}_{0}\right)$ ditolak dan hipotesis alternative $\left(\mathrm{H}_{1}\right)$ diterima, apabila $\mathrm{r}_{\text {hitung }}$ $>r_{\text {tabel }}$. Adapun pengujian hipotesis 1 (pertama), dalam hal ini menguji tentang tingkat pendidikan orang tua dengan prestasi belajar siswa kelas VIII di MTs Azzainiyah 1 Randumerak tahun pelajaran 2013/2014. Ada pengaruh positif tingkat pendidikan orang tua dengan prestasi belajar siswa kelas VIII di MTs Azzainiyah 1 Randumerak.

\section{Pengaruh tingkat pendapatan orang tua $\left(X_{2}\right)$ dengan prestasi belajar siswa (Y)}

Sesuai dengan data yang tercantum pada table 4.8 di atas, diketahui bahwa nilai probabilitas signifikansi $\mathrm{X}_{2}=$ 0,011. Angka tersebut lebih kecil dari angka $0,05 \quad(0,011<0,05)$ yang merupakan angka derajat kepercayaan, maka dapat disimpulkan bahwa terdapat pengaruh yang signifikan antara tingkat pendapatan orang tua dengan prestasi belajar siswa kelas VIII di MTs Azzainiyah 1 Randumerak tahun pelajaran 2013/2014.

Dalam pengujian hipotesis penelitian ini, kriteria yang dipakai adalah sebagai berikut:

Hipotesis nol $\left(\mathrm{H}_{0}\right)$ diterima dan hipotesis alternative $\left(\mathrm{H}_{1}\right)$ ditolak, apabila $r_{\text {hitung }}<r_{\text {tabel }}$.

Hipotesis nol $\left(\mathrm{H}_{0}\right)$ ditolak dan hipotesis alternative $\left(\mathrm{H}_{1}\right)$ diterima, apabila $\mathrm{r}_{\text {hitung }}$ $>r_{\text {tabel}}$.Adapun pengujian hipotesis 1 (pertama), dalam hal ini menguji tentang tingkat pendapatan orang tua dengan prestasi belajar siswa kelas VIII di MTs Azzainiyah 1 Randumerak tahun pelajaran 2013/2014. Ada pengaruh positif tingkat pendapatan orang tua dengan prestasi belajar siswa kelas VIII di MTs Azzainiyah 1 Randumerak. 


\section{Uji Simultan (Uji F)}

Guna mengetahui hubungan variabel bebas secara simultan atau bersamasama (tingkat pendidikan dan tingkat pendapatan orang tua) dengan variabel terikat (prestasi belajar siswa), maka dilakukan uji $\mathrm{F}$ atau uji Anova. Uji F dapat dicari dengan membandingkan hasil dari probabilitas value. Apabila probabilitas value $>0,05$ maka $\mathrm{H}_{0}$ diterima dan $\mathrm{H}_{1}$ ditolak, namun jika probabilitas $<0,05$ maka $\mathrm{H}_{0}$ ditolak dan $\mathrm{H}_{1}$ diterima (Priyatno, 2010). Berikut ini adalah table hasil perhitungan Anova. Dari table 4.9 di atas dapat dilihat probabilitas value dalam penelitian ini sebesar 0,000 yang berarti angka ini berada di bawah angka 0,05 sehingga $\mathrm{H}_{0}$ ditolak dan $\mathrm{H}_{1}$ diterima. Hal tersebut menunjukkan bahwa ada pengaruh yang signifikan tingkat pendidikan orang tua dan tingkat pendapatan orang tua dengan prestasi belajar siswa kelas VIII di MTs Azzainiyah 1 Randumerak tahun pelajaran 2013/2014.

\section{Koefisien Determinasi}

Persentase hubungan semua variabel independent dengan variabel dependent ditunjukkan oleh besarnya koefisien determinasi $\left(\mathrm{R}^{2}\right.$ atau $\mathrm{R}$ square). Koefisien determinasi $\left(\mathrm{R}^{2}\right.$ atau $\mathrm{R}$ square) ini menunjukkan seberapa besar hubungan variabel bebas dengan variabel terikat dan dinyatakan dalam bentuk persen (Algifari, 2000). Berikut ini adalah table hasil perhitungan Model Summary

\section{Kriteria pengujian hipotesis:}

Dalam peng ujian hipotesis penelitian ini, kriteria yang dipakai adalah sebagai berikut Hipotesis nol $\left(\mathrm{H}_{0}\right)$ diterima dan hipotesis alternative $\left(\mathrm{H}_{1}\right)$ ditolak, apabila $r_{\text {hitung }}<r_{\text {tabel }}$. Hipotesis nol $\left(\mathrm{H}_{0}\right)$ ditolak dan hipotesis alternative $\left(\mathrm{H}_{1}\right)$ diterima, apabila $r_{\text {hitung }}>r_{\text {tabel }}$. koefisien determinasi ( $\mathrm{R}^{2}$ atau $\mathrm{R}$ square) dalam model summary diketahui nilai $\mathrm{R}$ Square adalah 0,629 atau 62,9\%. Nilai tersebut menunjukkan besarnya pengaruh yang diberikan oleh variabel independent (tingkat pendidikan dan pendapatan orang tua) dengan variabel dependent (prestasi belajar siswa), sedangkan sisanya yaitu sebesar $37,1 \%$ diterangkan oleh factor-faktor lain yang tidak diteliti dalam penelitian ini. Dengan demikian dapat disimpulkan dari hasil uji $r$ di atas menyatakan bahwa $r_{\text {hitung }}>r_{\text {tabel. }}$. Hal ini berarti dengan tingkat kepercayaan 5\% hipotesis alternative $\left(\mathrm{H}_{1}\right)$ diterima dan hipotesis nol $\left(\mathrm{H}_{0}\right)$ ditolak.

Berdasarkan temuan data penelitian dan analisis data maka dapat dijabarkan sebangai berikut:

a. Pendidkan terperoses aktifitas dan mencapai tujuan tertentu. Dikatakan terperoses karena terdapatnya beberapa pengarauh yang sama mempunyai peranan waktu yang berkesenambungan. Sesuai dari analisis data kuesioner untuk variabel tingkat pendidikan orang tua di ketahuai bawa, Berdasarkan data di atas diketahui bahwa tingkat pendidikan yang berkategori sangat tinggi adalah perguruan tinggi (PT) adalah 0 orang $(0 \%)$, kategori tinggi atau setingkat SMA/sederajat sebanyak 8 orang $(38 \%)$, kategori cukup adalah setingkat SMP sebanyak 8 orang $(38 \%)$, kategori rendah adalah setingkat SD yaitu sebanyak 5 orang (24\%) dan kategori sangat rendah yaitu orang yang tidak pernah sekolah sebanyak 0 orang $(0 \%)$. Dengan demikian tingkat pendidika orang tua siswa kelas VIII di MTs Azzainiyah 1 Randumerak dalam kategori tinggi atau tamat SMA/sederajat dan cukup atau tamat 
SMP yang masing-masing sebanyak 8 orang.

b. Pendapatan merupakan semua penerimaan seseorang sebagai balas jasanya dalam proses produksi.berdasarkan dari data angket dari 21 siswa adalah dengan melakukan pensekoran perhitungan yang di lakukan peneliti dalam masing masing fariabel. Dari data tersebut Dari data tersebut terlihat bahwa tingkat pendapatan orang tua siswa dengan kategori sangat tinggi adalah 0 orang $(0 \%)$, kategori tinggi adalah 2 siswa atau $10 \%$, kategori cukup yaitu 2 orang atau $10 \%$, kategori rendah sebanyak 11 orang atau $52 \%$ dan kategori sangat rendah sebanyak 6 orang atau 29\%. Dengan demikian secara umum dapat dikategorikan bahwa tingkat pendapatan orang tua siswa kelas VIII di MTs Azzainiyah 1 Randumerak berada dalam taraf rendah yang lebih dominan.

c. Prestasi belajar perubahan tingkah laku yang berwujut perubahab ilmu pengetahuan, keterampilan motorik sikap dan nilai yang dapat di ukur secara aktual sebangai hasil dari proses belajar. Berdasarkan perhitungan frekunsi dalam mata pelajaran IPS kelas VIII adalah terlihat bahwa siswa yang mendapat prestasi belajar dengan kategori sangat tinggi adalah 5 siswa atau $24 \%$, kategori tinggi sebanyak 7 siswa atau 33\%, kategori cukup juga sebanyak 7 siswa atau 33\%, kategori rendah sebanyak 1 orang atau 5\% dan kategori sangat rendah juga sebanyak 1 orang atau 5\%. Dengan demikian dapat dikatakan bahwa sebagian besar siswa dapat dikategorikan mendapat nilai tinggi dan cukup.

d. Guna mengetahui hubungan variabel bebas secara simultan atau bersama- sama (tingkat pendidikan dan tingkat pendapatan orang tua) dengan variabel terikat (prestasi belajar siswa), maka dilakukan uji $\mathrm{F}$ atau uji Anova. Uji F dapat dicari dengan membandingkan hasil dari probabilitas value. Apabila probabilitas value > 0,05 maka $\mathrm{H}_{0}$ diterima dan $\mathrm{H}_{1}$ ditolak, namun jika probabilitas <0,05 maka $\mathrm{H}_{0}$ ditolak dan $\mathrm{H}_{1}$ diterima (Priyatno, 2010).Dari pengujian tingkat pendidikan dan tingkat pendapatan dengan fariabel terikat dalam penelitian ini sebesar 0,000 yang berarti angka ini berada di bawah angka 0,05 sehingga $\mathrm{H}_{0}$ ditolak dan $\mathrm{H}_{1}$ diterima. Hal tersebut menunjukkan bahwa ada pengaruh yang signifikan tingkat pendidikan orang tua dan tingkat pendapatan orang tua dengan prestasi belajar siswa kelas VIII di MTs Azzainiyah 1 Randumerak tahun pelajaran 2013/2014.

\section{KESIMPULAN}

Berdasarkan hasil analisis dan pembahasan Bab IV maka dapat diambil kesimpulan sebangai berikut:

1. Terdapat pengaruh yang signifikan antara tingkat pendidikan orang tua dengan prestasi belajar siswa kelas VIII di MTs Azzainiyah 1 Randumerak tahun pelajaran 2013/2014.

2. Terdapat pengaruh yang signifikan antara tingkat pendapatan orang tua dengan prestasi belajar siswa kelas VIII di MTs Azzainiyah 1 Randumerak tahun pelajaran 2013/2014

3. Terdapat pengaruh yang signifikan tingkat pendidikan orang tua dan tingkat pendapatan orang tua dengan prestasi belajar siswa kelas VIII di 
MTs Azzainiyah 1 Randumerak tahun pelajaran 2013/2014.

\section{DAFTAR RUJUKAN}

Ardy wiyani.(2013). Psikologi Pendidikan. Yogyakarta: Ar Ruzz Media.

Arikonto, Suharsimi. 2010. Prosedur Penelitian Suatu Pendekatan Praktik. Jakarta : Renika Cipta 2010.

Hadikusumo, Kunaryo. 2000. Pengantar Pendidikan. Semarang: IKIP Semarang PRESS.

Margono S. 2007. Metode Penelitian Pendidikan. Jakarta: PT.Rineka Cipta.

Nurhayati, T. Kurnia. 2003. Kamus Lengkap Bahasa Indonesia. Jakarta : Eka Media.

Singgih Santoso. 2000. Buku Latihan Spss Statistic Parametric. Jakarta : PT Elex Media Komputindo http://www.iisip.ac.id/content/pen garuh-status-sosial-ekonomikeluarga-terhadap-prestasibelajar-siswa-kelas-x-di-smaneger. status sosial ekonomi.pada tanggal 06 Februari 2014. Pukul 22.35 WIB.

Slameto. 2010. Belajar dan FaktorFaktor yang Mempengaruhinya. Jakarta : PT Rineka Cipta.

Soekanto, Soejono 2001. Kamus Sosiologi. Jakarta: CV. Rajawali.

Sugiono. 2013. Metode Penelitian Pendidikan Pendekatan Kualitatif Kuantitatif dan $R \& D$. Bandung: Alfabeta.
Suharsimi Arikunto. 1998. Prosedur Penelitian suatu pendekatan Praktek.Jakarta : Rineka Cipta.

Suharsimi Arikunto. 2002. Prosedur Penelitian Suatu Pendekatan Praktek. Jakarta : PT.Rineka Cipta.

Suharsimi Arikunto. 2006. Prosedur Penelitian Suatu Pendekatan Praktek. Jakarta : PT. Rineka Cipta.

Suharsimi Arikunto. 2007. Dasar-dasar evaluasi Pendidikan. Edisi revisi. Jakarta :PT. Bumi Aksara.

Undang-Undang Sistem Pendidikan Nasional (UU no 20/2003). Jakarta: Sinar Grafika. 